\title{
ABSTRACT NOUNS AS METADISCURSIVE SHELLS IN ACADEMIC DISCOURSE
}

\author{
ELS NOMS ABSTRACTES COM A ENCAPSULADORS \\ METADISCURSIUS EN EL DISCURS ACADÈMIC
}

\author{
Mercedes Díez Prados \\ University of Alcalá \\ mercedes.diez@uah.es
}

Abstract: Academic discourse is characterized by an abundance of abstract nouns such as analysis, research, process, concept, approach or role. These nouns are considered cohesive devices since their full content is determined by referring to their context and they have received numerous denominations (anaphoric, signaling, carrier, shell or metadiscursive nouns). This paper explores the metadiscursive role of shell nouns in a corpus of academic abstracts written by university students for their Senior Theses, based on Schmid's (2000) and Jiang and Hyland's (2016, 2017) proposals. The rhetorical, persuasive potential of these abstract nouns in this type of academic discourse is also addressed. The results show that advanced EFL writers deploy a wide range of abstract nouns in patterns that resemble those of scholars (Jiang \& Hyland 2017). Different moves in the text seem to influence the type of noun employed. All in all, advanced English Studies majors are aware of academic disciplinary conventions but would benefit from training in abstract writing, particularly in the distribution of the text's moves.

Key words: metadiscursive nouns, shell nouns, cohesion, persuasion, academic discourse.

Resum: El discurs acadèmic es caracteritza per l'abundància de noms abstractes, com ara anàlisi, recerca, procés, concepte, aproximació o rol. Considerats mecanismes cohesius, atès que el seu significat discursiu es determina per referència al context en què apareixen, han rebut denominacions diverses en la bibliografia anglosaxona (anaphoric, signaling, carrier, shell o metadiscursive nouns). A partir de les propostes de Schmid (2000) i Jiang i Hyland (2016, 2017), aquest article explora la funció metadiscursiva d'aquests noms com a encapsuladors d'informacions complexes en un corpus de resums acadèmics elaborats per estudiants universitaris per als seus Treballs de Final de Grau. El treball aborda també el potencial retòric i persuasiu d'aquests noms abstractes en 
aquest gènere acadèmic. Els resultats palesen que els estudiants de nivell avançat d'anglès com a llengua estrangera utilitzen una àmplia gamma de substantius abstractes i segueixen patrons d'ús que s'assemblen als dels experts acadèmics (Jiang i Hyland 2017). Les diferents parts l'estructura textual semblen condicionar el tipus de nom emprat. En definitiva, tot i que els estudiants quasigraduats d'Estudis Anglesos mostren que coneixen les convencions del gènere, els resultats millorarien si, durant el desenvolupament del grau, s'incidís en l'elaboració de resums de treballs acadèmics (abstracts), sobretot pel que fa a l'organització de la informació.

Paraules clau: noms metadiscursius, noms encapsuladors, cohesió, persuasió, discurs acadèmic.

\section{$\operatorname{cosectats}$}

\section{INTRODUCTION}

Abstract nouns such as analysis, characteristic, fact or aim are broad-meaning and multifunctional nouns that have attracted the attention of scholars for decades, having received various names: general nouns (Halliday \& Hasan I976), carrier nouns (Ivanič 199I), anaphoric nouns (Francis 1986), labels (Francis 1994), encapsulators, signaling nouns (Flowerdew 2006), and, more recently, metadiscursive nouns (Tahara 20I4; Jiang \& Hyland 2016, 2017).

Since Halliday and Hasan's (1976) term general noun seems too general and fuzzy to delimit the category, each new term is an attempt to focus on an outstanding feature of these nouns. For instance, anaphoric noun (Francis's term) refers to the textual situation of the noun's propositional content, carrier noun (Ivaničs's) was coined to encompass clause and exophoric uses, and signaling noun (Flowerdew's) allows reference to be situated anaphorically, cataphorically, or even exophorically; the term shell noun (Schmid 2000) highlights the cognitive function of these nouns, where the content referenced to is considered to be a mental construct, although based on a textual chunk of discourse. The last term coined, metadiscursive noun, is, according to Jiang and Hyland (2017: 3), an attempt by Tahara (2014) to include all dimensions of previous studies; however, Jiang and Hyland (2016, 2017) believe that Tahara's treatment does not do full justice to these nouns' functions; while adopting the term, they provide it with additional rhetorical functions by covering textual and interpersonal features. These dimensions are named, respectively, interactive and interactional; the former refers to the construction of cohesion and the latter to the expression of stance. 
The methodological framework adopted in this study incorporates the metadiscursive approach proposed in the most recent publications by Jiang and Hyland (2016, 20I7) and is merged with one of the two "large-scale studies of this type of noun» (Jiang \& Hyland 2017:3), Schmid's (2000) English Abstract Nouns as Conceptual Shells. ${ }^{1}$ Since the abstract nouns analyzed in this article belong to the academic disciplinary discourse, the shorthand label academic abstract noun will be used, together with the merged denomination of metadiscursive shell noun.

Making adequate rhetorical choices in academic discourse contributes to achieving effective persuasion, which is particularly the case in the academic genre chosen for analysis: the research abstract, specifically when written as part of undergraduate senior theses; this type of speech act is socially situated in a disciplinary or institutional context (Hyland 2005a: 175). To be convincing and, thus, to be evaluated positively by the reader, a member of the academic committee who assesses these research papers, one needs to connect with a discursive communal ideology or value system. The use of metadiscursive shell nouns is one type of rhetorical tool to fulfill this requirement.

Focusing on the use of abstract nouns in academic discourse, this study is guided by the following research questions:

(a) What types of metadiscursive shell nouns are used by writers in the abstracts analyzed? What is the frequency of occurrence of metadiscursive shell nouns in abstracts written by university students (i.e. novice research writers)?

(b) What are the most frequent lexico-grammatical patterns in which these nouns are used? Are the results comparable with those from a study by expert research writers (Jiang and Hyland 2017)?

(c) How do metadiscursive nouns organize cohesion in the text?

(d) Do abstractsfollow the IMRD (i.e. Introduction-Method-Results-Discussion) pattern and what is the role of metadiscursive nouns in the pattern moves?

In order to answer these questions, a multidimensional analysis will be carried out, addressing the issues raised in each question:

(a) Identification and classification of metadiscursive shell nouns, following Jiang and Hyland's (2016, 2017) categorization, and resorting to Schmid's (2000) and

I. The other large-scale study pointed out by these authors (Jiang \& Hyland 20I7: 3) is Flowerdew and Forest's (2015).

Caplletra 64 (Primavera, 2018), pp. 153-178 
Flowerdew's (2006) classifications. This analysis addresses what Jiang and Hyland (20I7) denominate the interactional dimension.

(b) Identification of the lexico-grammatical patterns in which the nouns are used, expanding Schmid's (2000) and Jiang and Hyland's (2016, 2017) taxonomy to include all patterns found.

(c) Identification of cohesive relations established by the academic abstract nouns found, according to Jiang and Hyland's (2017) interactive dimension.

(d) Identification of the rhetorical moves (i.e. Introduction-Purpose-MethodsResults-Conclusion) in the abstracts selected, following Jiang and Hyland's (2017) study, focusing on the role academic abstract nouns play in each move.

The next section presents and explains the concept of «metadiscursive shell noun» and is followed by a section devoted to the theoretical framework adopted. Section 4 justifies the persuasive function played by the genre chosen for analysis, the academic abstract. Section 5 discusses the details of the empirical study: corpus, participants and analytical method employed; and Section 6 presents and interprets the results focusing on the four analyses carried out: I) interactional dimension, 2) lexico-grammatical patterns, 3) interactive dimension (i.e. cohesion), and 4) rhetorical moves. Finally, Section 7 provides the conclusions for the present study.

\section{ACADEMIC ABSTRACT NOUNS AS METADISCURSIVE SHELLS}

Shell nouns are defined by Schmid (2000: 13) as an open class of nouns that are recognized by their functional potential rather than by their inherent properties. He considers them "conceptual shells» because their main function is to supply and conceptualize the information contained in propositions. Although called by Francis (I986) anaphoric nouns (A-nouns for short), this type of noun can advance information that comes later in the text, functioning cataphorically. Apart from this textual cohesive function attributed to shell nouns, they have the potential to conceptualize complex ideas into manageable notions (i.e. gestalt formation, Schmid 2000: 376) and can even have an interactional dimension (Jiang \& Hyland 2017).

Metadiscursive nouns are a subset of abstract nouns and are defined «as those which refer to the ORGANIZATION OF THE TEXT [i.e. interactive dimension] or the WRITERS' ATTITUDE TOWARDS IT [i.e. interactional dimension] [emphases and explanations added]" (Jiang \& Hyland 20I7: I-2). According to these authors, such nouns have an invariable lexical meaning and a variable, context-dependent, pragmatic one. Jiang 
and Hyland (2016: I0) mention that theirs is a more pragmatic, functional approach than others, like Schmid's (2000) or Flowerdew and Forest's (2015), who give greater prominence to the semantic meaning of these nouns. Even if a pragmatic classification is desirable because it allows the context to be taken into account, this approach is not feasible in large-scale studies like the ones previously mentioned, since large corpora must be analyzed with retrieval software that enables generic searches but is limited with regards to contextual analyses.

The present corpus can be coded manually for its manageable proportions (4646 words); however, semantic approaches like Schmid's (2000) provide the necessary scaffolding for contextually based analyses like the present one. Furthermore, Schmid (2000) is fully aware of the pragmatic dimension of these abstract nouns, as he devotes a whole chapter to the pragmatic, rhetorical and textual functions of these nouns, as well as mentioning their pragmatic function elsewhere in his book. Not only Schmid (2000) but also Jiang and Hyland (2017) mention the rhetorical potential for persuasion of shell or metadiscursive nouns (or, merging both, metadiscursive shell nouns). According to Schmid (2000: 8), «shell nouns provide speakers with powerful tools for the characterization, perspectivization, and indeed even manipulation, of their own and other speakers' ideas» and, in Jiang and Hyland's words (2017: I), «these nouns help writers organize their arguments and persuade disciplinary peers of their claims». For Jiang and Hyland (2017: 2), their persuasive function relies mainly on their potential to express stance and engagement in Hyland's (2005a, 2005b) terms, the two manifestations of evaluation. Stance refers to the expression of judgements, opinions and commitments by means of hedges, boosters, attitude markers and selfmention, while engagement involves the alignment of writers/speakers with readers/ hearers via reader/speaker pronouns, directives, questions, appeals to shared knowledge and personal asides (Hyland 2005a).

Metadiscursive nouns are called so because they "perform evaluative and engagement roles, either expressing the writer's stance to the message or involving readers as discourse participants through appeal to shared knowledge and awareness of rhetorical practices» (Jiang \& Hyland 2017: 2). The present study addresses the latter dimension of shell nouns, that is, their use as rhetorical tools for persuasion. 


\section{THEORETICAL FRAMEWORK FOR THE ANALYSIS OF ACADEMIC ABSTRACT NOUNS}

There are certain correspondences between Jiang and Hyland's (2016, 20I7) categories and Schmid's (2000) types of abstract nouns that allow complementation of models: Relation in Jiang and Hyland's is somewhat equivalent to Factual in Schmid, Discourse to Linguistic, Cognition to Mental, Status to Modal, Manner to Circumstantial and Event to Eventive; Object (called Text in Jiang \& Hyland 2016: 17) can be subsumed within Linguistic and Quality with Factual. Another classification of nouns that can be taken as a point of reference is Flowerdew's (2006) list of academic nouns. table I includes Jiang and Hyland's (2017) classification, which is the one used in the present study.

\begin{tabular}{|l|l|l|}
\hline \multicolumn{2}{|c|}{ Category } & \multicolumn{1}{c|}{ Definition } \\
\hline \multicolumn{3}{|c|}{ Entity } \\
\hline Object & Concrete metatext & article, paper, study \\
\hline Event & Events, processes and evidential cases & change, case, observation \\
\hline Discourse & Verbal propositions and speech acts & argument, claim, conclusion \\
\hline Cognition & Cognitive beliefs and attitudes & decision, idea, notion, aim \\
\hline \multicolumn{3}{|c|}{ Attribute } \\
\hline Quality & $\begin{array}{l}\text { Traits that are admired or criticized, valued } \\
\text { or depreciated. }\end{array}$ & Advantage, diffculty, failure \\
\hline Manner & Circumstances of actions and states of affairs. & Time, method, way, extent \\
\hline Status & Epistemic, deontic and dynamic modality. & Possibility, trend, choice, ability \\
\hline \multicolumn{3}{|c|}{ Relation } \\
\hline $\begin{array}{l}\text { Cause-effect, } \\
\text { difference, etc. }\end{array}$ & Cause-effect, difference, relevance. & Reason, result, difference \\
\hline
\end{tabular}

Table I. Jiang and Hyland's (2017) categorization of metadiscursive nouns

Jiang and Hyland (2016, 2017) closely follow Schmid (2000) not only in their categorization of abstract nouns but also in the identification of the lexico-grammatical patterns in which these nouns most typically appear (see Table 2). 


\begin{tabular}{|c|c|}
\hline Patterns and examples in Schmid (2000: 22) & $\begin{array}{l}\text { Patterns and examples in Jiang \& Hyland } \\
(2017: 2)\end{array}$ \\
\hline $\begin{array}{l}\text { Th-N (But what does it all mean? }[. . .] \text { the full } \\
\text { answer to that question)* }\end{array}$ & $\begin{array}{l}\text { Determiner }+\mathrm{N} \text { (these opposing tendencies }[\ldots] \\
\text { strong dissipation. This insight motivates }[\ldots])\end{array}$ \\
\hline $\begin{array}{l}\text { Th-be-N }([\ldots] \text { it has }[\ldots] \text { introduced the idea } \\
\text { that people should .... that is a crucial point })\end{array}$ & $\begin{array}{l}\text { Determiner }+b e+N([\ldots] \text { our intuition about } \\
\text { skepticism. This is the hard problem for indirect } \\
\text { sensitivity accounts. })\end{array}$ \\
\hline $\begin{array}{l}\text { N-cl }([\ldots] \text { his belief that intervention could } \\
\text { draw the UN into }[\ldots])\end{array}$ & $\begin{array}{l}\mathrm{N}+\text { post-nominal clause (This research examines } \\
\text { the notion that guilt, the negative emotion stem- } \\
\text { ming from }[\ldots])\end{array}$ \\
\hline $\begin{array}{l}\text { N-be-cl }([\ldots] \text { the eventual aim is to set up a new } \\
\text { discipline }[\ldots])\end{array}$ & $\begin{array}{l}\mathrm{N}+b e+\text { complement clause (The aim of this } \\
\text { study was to determine if differences in coronary } \\
\text { endothelial function [...]) }\end{array}$ \\
\hline
\end{tabular}

${ }^{*}$ Bold: shell noun. Underlined: shell content.

Table 2. Lexico-grammatical patterns in Schmid (2000) and Jiang \& Hyland (2017)

The types of clauses that tend to follow the shell noun are established by Schmid as that-clauses, infinitive clauses and wh-clauses. Although Jiang and Hyland (2016:5) refer to Schmid (2000) when identifying the «four most frequent lexico-grammatical patterns in which metadiscursive nouns are used», in fact, the patterns are not totally identical, as can be seen in table 2 .

An unclear area in Jiang and Hyland's treatment of lexico-grammatical patterns is whether all determiners should be included in the patterns or just demonstratives, since they use the latter term in a previous publication (Jiang \& Hyland 20I6). Guided by the examples collected from both publications, the broader category of Determiner has been adopted: [...] supported by the observation (Jiang \& Hyland 2016: 4) and According to the traditional view [...] (Jiang \& Hyland 2016: 5, 2017: 2).

The identification and categorization of abstract metadiscursive nouns in my study corresponds to the interactional dimension highlighted in Jiang and Hyland's (2016, 2017) model; this function is justified because they are used «to express the writer's stance or engage readers in the argument» (Jiang \& Hyland 20I7: 8). These nouns are classified by these authors according to their stance function (see table I), which corresponds fairly closely, as explained above, with Schmid's six-category semantic model (factual, linguistic, mental, modal, eventive and circumstantial).

The interactional dimension is complemented by an interactive dimension, which addresses cohesive relations (cf. Jiang \& Hyland 2016, 20I7). The concept of cohesion that Halliday and Hasan (I976) developed in their seminal study Cohesion in English only considers as cohesive devices reference within the text (i.e. endophoric 
reference); thus, exophoric reference is not cohesive. Although this is the approach adopted in previous studies (Díez Prados 200I, 2003; Díez, Halbach \& Rivas 2002; Díez Prados \& Cabrejas Peñuelas 20I2; Cabrejas Peñuelas \& Díez Prados 20I3), the present one does not constrain cohesion to the relations within the textual world, like other scholars do (Brown \& Yule 1983; Christiansen 20II).

Jiang and Hyland (2016:5) believe that «in all cases the metadiscursive noun provides a link with additional information, whether inside or outside the text [which] helps writers move ideas along cohesively and to assist readers to gain a better comprehension of the connected information». Thus, it seemed advisable to adopt this theoretical conception here. An example of exophoric reference they mention is "according to the traditional view», and they explain that, in order to provide content to the noun, readers must summon «a referent from their background knowledge outside the current text» (Jiang \& Hyland 2016: 5). Therefore, examples like these have been included and analyzed as exophoric in the present corpus.

A further justification for considering both endophoric and exophoric cohesion is found in Schmid (2000: 29), who claims that the location of referents is not always unambiguous, bearing in mind that readers may be resorting to a mental representation of referents. In that case, all coreferentiality would be exophoric and «activation of components of a cognitive model [emphasis in the original] solves the problem inherent in the claim that shell nouns and the linguistic elements expressing the shell content have to do with the same thing» (Schmid 2000: 29).

Schmid's work (2000) is the first large-scale attempt to regulate and classify an extensive and not easily delimiting group of nouns that are prevalent across disciplinary discourses. However, when deciding on which methodological framework to use, Jiang and Hyland's (2017) notion of metadiscursive noun was adopted for two main reasons: $(a)$ the discourse genre to be analyzed, the abstract, coincides with the one in these author's study; and (b) their multidimensional analysis (rhetorical moves, interactive and interactional dimensions) seemed suitable for focusing on the rhetorical function of these nouns. The equivalence in the methodological framework between their study and the present one adds one more advantage: allowing the comparison of results between novice and expert research writers.

In the present study, the label shell noun has been maintained following Schmid's treatment of these nouns, which have three encompassing characteristics:

(a) Considering nouns as conceptual constructs allows the inclusion of all previous notions of containment, signaling, pointing and encapsulating (Schmid 2000: 13).

(b) Schmid's (2000) study encompasses the use of these nouns in a broad range of different text types and, thus, provides a picture of their use in an interdisciplinary 
fashion. His list of shell nouns is the result of a systematic analysis of a wide-ranging corpus (COBUILD's Bank of English, 320 million words) and includes 670 lexemes (the list is available in the Appendix, pp. 443-452), which are categorized and explained according to their six different uses. This characteristic confers on Schmid's (2000) publication the nature of a manual for research purposes.

(c) Schmid's treatment of reference as a cognitive phenomenon (2000: $27 \mathrm{ff}$.) instead of a textual one subsumes all types of reference (anaphora, cataphora and deixis or exophora), since the relation between the referential expression and its referent is established in the mind. For him, «items with referring potential are seen as being related neither to the text itself nor to the world outside the text but to the cognitive models that are created in the minds of language users» (Schmid 2000: 28). This solves the arduous task, at times, of deciding the exact location of the shell noun's content.

The aforementioned considerations justify the adoption of a theoretical framework resulting from the merge of Schmid's and Jiang and Hyland's model, together with the coinage of a new term for this type of academic abstract noun: metadiscursive shell nouns. In the following section, the promotional function of academic abstracts is explained and their relevance justified.

\section{ACADEMICABSTRACTS AS PROMOTIONAL PERSUASIVE DISCOURSE}

Academic abstracts may be considered a type of promotional persuasive discourse; due to their main function of «selling» an idea to a potential «client», they somehow resemble entrepreneurialpitches since they are both examples of brief self-promotional text. The entrepreneurial pitch is an up to three-minute oral presentation to defend a project, idea, product, service or organization, mainly to obtain financial support; likewise, the function of academic abstracts is to promote the author's research and to help readers judge the relevance and interest of a given study to decide whether to continue reading or reject the article altogether (Jiang \& Hyland 2017: 3). In that sense, both promotional genres try to highlight the special contribution or personal brand of the persuader: in the case of the entrepreneurial pitch, its unique selling point (USP), and in academic abstracts, a proposal for how to fill a research gap.

The purpose of abstracts is, therefore, persuasion, and, as such, they have to influence somehow the reader's value system (García-Gómez 2007) or faltering beliefs (Jaffe 2007). To do so, writers in an academic discourse community have to adapt their discourse to their readers' expectations to convince them of their value as 
members of the community. If expert and novice writers are not fully aware of the promotional value of abstracts, they may not devote enough time and effort to their design. Furthermore, writing an appropriate abstract is not an easy task, due to its synthetic nature; one needs to extract what is most important and worth highlighting from the paper and, at the same time, it should form a coherent whole.

Persuasion is a communicative function that pervades most discourse types. Although the main function of academic abstracts may not be persuasive per se, the role they fulfill with respect to the expectations of the reader that is to evaluate the paper credits this academic genre as a sort of cover letter that may predispose the actual addressee (un)favorably. Despite its importance, abstract writing is often disregarded as an unimportant and somehow tedious task by students. However, metadiscursive nouns in abstracts help the writer to meet this rhetorical challenge because they are versatile and functional; hence, these nouns play a relevant role in EFL academic writing. As Jiang and Hyland (2017) show, abstracts contain a profusion of metadiscursive abstract nouns and both Ivanič (199I) and Flowerdew (2006) point out the importance of learners being acquainted with these nouns when they try to meet the requirements of the academic discourse community. This fact highlights the relevance of studies like the present one.

\section{EMPIRICAL STUDY: ABSTRACT NOUNS IN UNIVERSITY ACADEMIC DISCOURSE}

The Spanish university education system (Royal Decree I393/2007, 29 October) establishes the requirement to write a Senior Thesis (called in Spanish Trabajo de Fin de Grado, or TFG for short, which can be literally translated as Final Degree Paper) to obtain an undergraduate degree, whose main aim is to evaluate the competences associated with the corresponding degree. In the Modern Languages Department at the University of Alcalá (Spain), the degree in English Studies allows students to write a Senior Thesis either in the field of the literature and culture of English-speaking countries, or in the field of linguistics and the English language (applied linguistics, mainly, but within a broad range of approaches, such as Pragmatics, Discourse Analysis, Cognitive Linguistics, Corpus Linguistics, Historical Linguistics, EFL, etc.). The students who decide to write their paper on linguistics are advised to structure their project according to the general IMRD (Introduction-Methods-Results-Discussion, Swales and Feak 2009) pattern.

The corpus collected for the present study consists of 24 Senior Thesis abstracts (about 200 words each, a total of 4646 words) written in English as their foreign 
language by 24 undergraduates (I6 females and 8 males) of the degree of English Studies from the University of Alcalá (Spain); the main focus of study is their use of metadiscursive shell nouns, which allows for some comparison with Jiang and Hyland's (2017) results for abstracts written by well-established scholars in different academic disciplines in high-impact journals.

Following Jiang and Hyland's (2017) study, the 24 abstracts were analyzed in a multilayered fashion, which involved the following steps:

Step I. Identification and classification of metadiscursive abstract nouns in the following phases:

(a) The metadiscursive abstract nouns identified were assigned to Jiang and Hyland's categorization, if included on their list (Jiang \& Hyland 20I6).

(b) If absent, the noun was searched for in Schmid's Index of Shell Nouns (Schmid 2000: 443-452) and, if found, assigned to one of Jiang and Hyland's (2016, 20I7) categories. Comparisons among nouns helped establish the category to which the noun might belong.

(c) If the noun was absent in both classifications but was present in Flowerdew's (2006: 354) list of the Ioo most common nouns in academic English, it was assigned to Jiang and Hyland's categorization (e.g. term was assigned the label «entity/discourse» by comparison with statement and proposition, i.e. to a class referred to linguistic entities stricto sensu).

(d) Finally, if the noun was not present in any classification but still seemed a feasible candidate to be classified as a metadiscursive shell noun, it was categorized in a group according to its meaning and function (e.g. enumeration was included within the group entity/object due to its resemblance to explanation or description from Jiang and Hyland's (2016) list).

The list of nouns found in the corpus analyzed, together with their categorization, has been included in table 4 below.

Step 2. Identification of the lexico-grammatical pattern in which the noun is used. In the present study, the ranges of determiners and clauses have been extended to include all the types found: Determiner + noun includes demonstratives (e.g. this

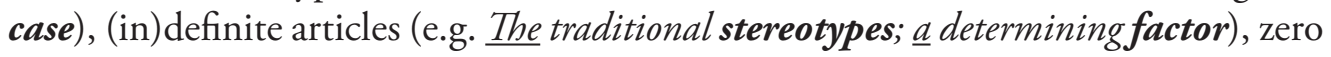
articles (e.g. more accurate Ø conclusions, where no article is required), possessive adjectives (e.g. their experience); indefinite adjectives (e.g. some examples), interrogative pronouns (e.g. which situation) and numerals (e.g. one situation).

The types of post-nominal clauses found in the Noun + clause structure were: Nominal that clause (e.g. evidence that $L_{2}$ is indeed built upon the native language), 
to-infinitive clause (e.g. an attempt to persuade others), wh-clause (e.g. the reasons why early after-perfect instances had a prospective tense), past participle clause (e.g. the information gathered), prepositional clause (e.g. a way of creating) and relative clause (e.g. a notion that needs further study); relative clauses are considered here although not included by Schmid (2000) because they help conceptualize the shell content or referent of the abstract noun. In the pattern Noun $+b e+$ clause, the only clause found was to-infinitive (e.g. my aim was to expose).

Step 3. Identification of cohesive relations: Three types of cohesive relations were taken into account: (a) Anaphoric (e.g. [...] whether romantic homosexual partners [...] In order to address this question [...]), (b) cataphoric (e.g. A further aim of this study is to compare [...D), and exophoric or deictic (e.g. [...] how traditional gender roles and stereotypes).

Step 4. Identification of rhetorical moves: the pattern Introduction-PurposeMethods-Results-Conclusion suggested by Jiang and Hyland (20I7: 4) was searched for in the abstracts.

The 4,646-word corpus ( 24 abstracts) was uploaded in text format and manually coded with the aid of UAM Corpus Tools, a freeware program developed by Mick O'Donnell. ${ }^{2}$ This software is, in fact, a set of tools to annotate the text(s), make searches in the corpus and run descriptive and inferential statistics. For the present study, four layers of analytical schemes were included in the program: Metadiscursive nouns, Lexico-grammatical patterns, Interactive cohesion and Rhetorical moves.

\section{RESULTS AND DISCUSSION}

This section presents and interprets the results gathered from the quantitative and qualitative analyses of metadiscursive shell nouns. It is subdivided into four parts, corresponding to the four analyses carried out and explained in the previous section.

2. The program can be downloaded for free from the web page: <http://www.wagsoft.com/ CorpusTool/>. 


\section{I RESULTS FOR THE INTERACTIONAL DIMENSION}

Table 3 includes the general results for metadiscursive nouns found, a total of 352 tokens. The most frequent category was Entity (60.51\%), particularly of the Cognition type (25.85\%) like hypothesis, aim, concept, theory, intention, knowledge, etc. (see table 4), followed by the Object type (18.47\%), which is a limited but frequent set of terms that refer to the work done (e.g. paper, research, study, thesis, project, dissertation). The types Discourse (e.g. expression, explanation, message, etc.) and Event (evidence, example, fact, finding, etc.) display similar frequencies ( $8.24 \%$ and $7.95 \%$, respectively). All the differences among categories and among types within categories are statistically significant ( $98 \%$ significance level).

\begin{tabular}{|c|c|c|}
\hline Feature & $\mathbf{N}$ & Percent \\
\hline METADISCURSIVE_NOUNTYPE & \multicolumn{2}{|c|}{$\mathrm{N}=352$} \\
\hline Entity & $2 \mathrm{I} 3$ & $60.51 \%$ \\
\hline Attribute & 87 & $24.72 \%$ \\
\hline Relation & 52 & $\mathrm{I} 4.77 \%$ \\
\hline ENTITY-TYPE & \multicolumn{2}{|c|}{$\mathrm{N}=352$} \\
\hline Object & 65 & $18.47 \%$ \\
\hline Event & 28 & $7.95 \%$ \\
\hline Discourse & 29 & $8.24 \%$ \\
\hline Cognition & 9I & $25.85 \%$ \\
\hline ATTRIBUTE-TYPE & \multicolumn{2}{|c|}{$\mathrm{N}=352$} \\
\hline Quality & 23 & $6.53 \%$ \\
\hline Manner & $5 \mathrm{I}$ & $\mathrm{I} 4.49 \%$ \\
\hline Status & $\mathrm{I3}$ & $3.69 \%$ \\
\hline RELATION-TYPE & \multicolumn{2}{|c|}{$\mathrm{N}=352$} \\
\hline Cause-effect_difference_etc. & 52 & $\mathrm{I} 4.77 \%$ \\
\hline
\end{tabular}

Table 3. Frequencies of metadiscursive nouns (tokens)

Nouns relating to Entities refer to the writer's judgement of texts, events, discourses or issues linked to cognition (Jiang \& Hyland 2017: 8). Within this class, the present corpus gives prominence to mental reasoning, beliefs or attitudes (i.e. Cognition type) and to the metatext (i.e. Object type), while verbal propositions and speech acts (i.e. Discourse type), and actions, processes or evidential cases (i.e. Event type) are less addressed. This prominence of Entities was also found in Jiang and Hyland (2017: 9), although the percentages are not that high (25.5\%). 
Nouns referring to Attributes constitute $24.72 \%$ of the text, and, when broken into groups, Status lexemes (i.e. expressions of modality) are scarce (3.69\%), both in number and in range; in fact, opportunity is the only lexeme found. Quality (6.53\%) doubles Status (3.69\%); these are terms that evaluate positively or negatively (e.g. advantage, challenge, idea, importance, problem or stereotype). Within the category of Attribute, the most frequent type of all is Manner (I4.49\%), a term that describes circumstances of actions or states of affairs, and has a wide variety of lexemes: area, characteristic, context, condition, method, pattern, technique or way.

Table 4 displays all the types of different nouns found, a total of ro9. Within categories, Entity shows more variety of nouns (60) than Attribute (35) or Relation (14). Of all subtypes, the largest variety of nouns is found in Cognition (29 different terms). Cognitive nouns are, thus, the most frequent (see table 3 ) and the most varied (see table 4 ).

\begin{tabular}{|c|c|c|}
\hline Category & Types of nouns & Total \\
\hline \multicolumn{2}{|r|}{ Entity } & 60 \\
\hline Object & $\begin{array}{l}\text { Investigation, work, dissertation, enumeration, essay, paper, project, research, } \\
\text { study, thesis }\end{array}$ & IO \\
\hline Event & $\begin{array}{l}\text { Attempt, case, criterion, evidence, example, experience, fact, factor, finding, } \\
\text { manifestation, phenomenon, process }\end{array}$ & $\mathrm{I} 2$ \\
\hline Discourse & $\begin{array}{l}\text { Answer, appeal, conclusion, explanation, expression, information, message, } \\
\text { question, term }\end{array}$ & 9 \\
\hline Cognition & $\begin{array}{l}\text { Aim, analysis, attitude, concept, conception, examination, focus, function, goal, } \\
\text { hypothesis, image, impression, insight, intention, issue, knowledge, notion, } \\
\text { objective, opinion, perception, perspective, position, prejudice, presupposition, } \\
\text { purpose, strategy, theory, topic, understanding }\end{array}$ & 29 \\
\hline \multicolumn{2}{|r|}{ Attribute } & 35 \\
\hline Quality & Advantage, challenge, idea, importance, problem, stereotype, success & 7 \\
\hline Manner & $\begin{array}{l}\text { Approach, situation, area, aspect, attribute, characteristic, condition, context, } \\
\text { distinction, factor, feature, framework, means, method, methodology, pattern, } \\
\text { structure, technique, tool, variable, way }\end{array}$ & $2 \mathrm{I}$ \\
\hline Status & Opportunity, capacity, choice, possibility, preference, requirement, role & 7 \\
\hline \multicolumn{2}{|r|}{ Relation } & I4 \\
\hline $\begin{array}{l}\text { Cause-effect, } \\
\text { difference, etc. }\end{array}$ & $\begin{array}{l}\text { Basis, comparison, connection, difference, differentiation, effect, effectiveness, } \\
\text { influence, outcome, reason, relation, relationship, result, similarity }\end{array}$ & I4 \\
\hline & TOTAL TYPES OF DIFFERENT NOUNS & I09 \\
\hline
\end{tabular}

Table 4. Academic abstract nouns (types)

In table 5 the use of nouns distributed among the different rhetorical moves can be seen. 


\begin{tabular}{|c|c|c|c|c|c|c|c|c|c|c|}
\hline \multirow[b]{2}{*}{ Feature } & \multicolumn{2}{|c|}{ Introduction } & \multicolumn{2}{|c|}{ Purpose } & \multicolumn{2}{|c|}{ Methods } & \multicolumn{2}{|c|}{ Results } & \multicolumn{2}{|c|}{ Conclusion } \\
\hline & $\mathrm{N}$ & Percent & $\mathrm{N}$ & Percent & $\mathrm{N}$ & Percent & $\mathrm{N}$ & Percent & $\mathrm{N}$ & Percent \\
\hline $\begin{array}{l}\text { METADISCURSIVE_NOUN- } \\
\text { TYPE }\end{array}$ & \multicolumn{2}{|r|}{$\mathrm{N}=80$} & \multicolumn{2}{|c|}{$\mathrm{N}=74$} & \multicolumn{2}{|c|}{$\mathrm{N}=78$} & \multicolumn{2}{|c|}{$N=75$} & \multicolumn{2}{|r|}{$\mathrm{N}=45$} \\
\hline Entity & 40 & $50.00 \%$ & $5 \mathrm{I}$ & $68.92 \%$ & 53 & $67.95 \%$ & 47 & $62.67 \%$ & 22 & $48.89 \%$ \\
\hline Attribute & $3 \mathrm{I}$ & $38.75 \%$ & $\mathrm{I2}$ & $\mathrm{I} 6.22 \%$ & 15 & $19.23 \%$ & $\mathrm{I2}$ & $16.00 \%$ & $\mathrm{I7}$ & $37.78 \%$ \\
\hline Relation & 9 & II. $25 \%$ & II & I4.86\% & I0 & $\mathrm{I} 2.82 \%$ & 16 & $2 \mathrm{I} .33 \%$ & 6 & $13.33 \%$ \\
\hline ENTITY-TYPE & \multicolumn{2}{|r|}{$\mathrm{N}=8 \mathrm{O}$} & \multicolumn{2}{|r|}{$\mathrm{N}=74$} & \multicolumn{2}{|c|}{$\mathrm{N}=78$} & \multicolumn{2}{|c|}{$\mathrm{N}=75$} & \multicolumn{2}{|c|}{$\mathrm{N}=45$} \\
\hline Object & I9 & $23.75 \%$ & 17 & $22.97 \%$ & $\mathrm{I2}$ & $15.38 \%$ & $\mathrm{II}$ & $14.67 \%$ & 6 & $13.33 \%$ \\
\hline Event & 3 & $3.75 \%$ & 5 & $6.76 \%$ & 7 & $8.97 \%$ & 8 & $10.67 \%$ & 5 & II.II \% \\
\hline Discourse & 2 & $2.50 \%$ & 4 & $5.4 \mathrm{I} \%$ & 8 & I0.26\% & 9 & $\mathrm{I} 2.00 \%$ & 6 & $13.33 \%$ \\
\hline Cognition & 16 & $20.00 \%$ & 25 & $33.78 \%$ & 26 & $33.33 \%$ & I9 & $25.33 \%$ & 5 & II.II \% \\
\hline ATTRIBUTE-TYPE & \multicolumn{2}{|r|}{$\mathrm{N}=8 \mathrm{o}$} & \multicolumn{2}{|r|}{$\mathrm{N}=74$} & \multicolumn{2}{|c|}{$\mathrm{N}=78$} & \multicolumn{2}{|c|}{$\mathrm{N}=75$} & \multicolumn{2}{|c|}{$\mathrm{N}=45$} \\
\hline Quality & 7 & $8.75 \%$ & 5 & $6.76 \%$ & 2 & $2.56 \%$ & 5 & $6.67 \%$ & 4 & $8.89 \%$ \\
\hline Manner & I9 & $23.75 \%$ & 6 & 8.II \% & $\mathrm{II}$ & I4.10\% & 6 & $8.00 \%$ & 9 & $20.00 \%$ \\
\hline Status & 5 & $6.25 \%$ & $\mathrm{I}$ & $1.35 \%$ & 2 & $2.56 \%$ & $\mathrm{I}$ & $\mathrm{I.} 33 \%$ & 4 & $8.89 \%$ \\
\hline RELATION-TYPE & \multicolumn{2}{|r|}{$\mathrm{N}=8 \mathrm{O}$} & \multicolumn{2}{|c|}{$\mathrm{N}=74$} & \multicolumn{2}{|c|}{$\mathrm{N}=78$} & \multicolumn{2}{|c|}{$\mathrm{N}=75$} & \multicolumn{2}{|r|}{$\mathrm{N}=45$} \\
\hline Cause-effect_difference_etc. & 9 & II. $25 \%$ & $\mathrm{II}$ & $\mathrm{I} 4.86 \%$ & IO & $\mathrm{I} 2.82 \%$ & 16 & $2 \mathrm{I} .33 \%$ & 6 & $13.33 \%$ \\
\hline
\end{tabular}

Table 5. Frequencies of metadiscursive nouns within rhetorical moves

With regard to the frequency of nouns within rhetorical moves, the Introduction and the Conclusion sections behave in similar ways since the only statistically significant difference between them is in the use of Entity/Discourse (nouns like answer, appeal, conclusion, explanation, etc.; see table 4). Most of these words are found in the Conclusion, where the results are interpreted (13.33\% in the Conclusion and only $2.5 \%$ in the Introduction). On the other hand, the Purpose, Methods and Results sections contain similar frequencies in terms of their use of Entity nouns (Purpose 68.92\%, Methods 67.95\% and Results 62.67\%) and Attribute nouns (Purpose I6.22 \%, Methods I9.23\% and Results $16 \%$ ); in fact, these differences are not statistically significant. Although Relation seems more frequently used in the Results section (2I.33\%), the difference among the rhetorical moves is only statistically significant $(\mathrm{p}<$.IO) when compared with Introduction (II.25\%).

Therefore, the core part of the abstracts (Purpose-Methods-Results) seems to behave similarly, and is in contrast to the beginning (Introduction) and the end of the abstracts (Conclusion). Specifically, the use of Entity is lower in the Introduction $(50 \%)$ and in the Conclusion (48.89\%) sections than in the Purpose (68.92\%), Methods $(67.95 \%)$ and Results (62.67\%) sections, whereas the use of Attribute is significantly higher in the Introduction $(38.75 \%)$ and in the Conclusion $(37.78 \%)$ than in the other three rhetorical moves (I6.22\% in Purpose, $19.23 \%$ in Methods and I6\% in Results). 
Within subtypes, Discourse is higher in the Conclusion ( $13.33 \%$ ) than in the rest of the moves (except when compared with Purpose, where the difference is not significant).

In order to determine what may be considered an adequate concentration of academic abstract nouns in short texts like abstracts, the measure academic abstract nouns index (AANI) is proposed. This index is the result of dividing the number of abstract nouns identified by the number of words in the text (expressed in percentages). That way the ratio obtained uncovers the density of academic abstract nouns used in relation to the total number of words. An excessive number of abstract words can tinge the text with a high degree of abstraction, which may result in a highly vague text, difficult to process and lacking specificity.

\begin{tabular}{|l|r|r|r|l|r|r|r|}
\hline \multicolumn{1}{|c|}{ Text } & \multicolumn{1}{c|}{$\begin{array}{c}\text { Total } \\
\text { words }\end{array}$} & \multicolumn{1}{c|}{$\begin{array}{c}\text { M-S } \\
\text { Nouns }\end{array}$} & \multicolumn{1}{c|}{ AANI } & \multicolumn{1}{c|}{ Text } & \multicolumn{1}{c|}{$\begin{array}{c}\text { Total } \\
\text { words }\end{array}$} & \multicolumn{1}{c|}{$\begin{array}{c}\text { M-S } \\
\text { Nouns }\end{array}$} & \multicolumn{1}{c|}{ AANI } \\
\hline TFG_Eng_I & I73 & 8 & 4.62 & TFG_Eng_13 & I44 & 8 & 5.56 \\
\hline TFG_Eng_2 & 242 & IO & 4.13 & TFG_Eng_I4 & 212 & I2 & 5.66 \\
\hline TFG_Eng_3 & I74 & I4 & 8.05 & TFG_Eng_15 & II5 & I0 & 8.70 \\
\hline TFG_Eng_4 & I89 & I8 & 9.52 & TFG_Eng_16 & I98 & I2 & 6.06 \\
\hline TFG_Eng_5 & 268 & I8 & 6.72 & TFG_Eng_17 & I79 & I4 & 7.82 \\
\hline TFG_Eng_6 & 222 & I6 & 7.21 & TFG_Eng_18 & 2I4 & II & 5.14 \\
\hline TFG_Eng_7 & I27 & I3 & I0.24 & TFG_Eng_19 & I46 & I2 & 8.22 \\
\hline TFG_Eng_8 & 255 & I9 & 7.45 & TFG_Eng_20 & I67 & IO & 5.99 \\
\hline TFG_Eng_9 & I55 & I4 & 9.03 & TFG_Eng_2I & I65 & I8 & I0.9I \\
\hline TFG_Eng_10 & 215 & II & 5.12 & TFG_Eng_22 & I36 & 9 & 6.62 \\
\hline TFG_Eng_II & 226 & I5 & 6.64 & TFG_Eng_23 & 311 & 46 & I4.79 \\
\hline TFG_Eng_12 & 293 & 24 & 8.19 & TFG_Eng_24 & I20 & I0 & 8.33 \\
\hline & Words & Nouns & AANI & & Words & Nouns & AANI \\
\hline TOTALS & 4,646 & 352 & 7.58 & MEANS & I93.58 & I4.67 & 7.53 \\
\hline
\end{tabular}

Table 6. Academic abstract noun indexes

As can be seen in Table 6, TFG 23, for example, has 3II words, 46 of which are academic abstract nouns. This lexical density of academic abstract nouns implies that $14.79 \%$ of the words in the text are metadiscursive nouns, when the mean for the whole corpus is half of that, $7.53 \%$. When TFG 23 is closely examined, that high degree of abstraction signaled by the AANI is ostensive:

[This study consists of the enumeration and analysis of several second language learning factors of influence together with the comparison of first and second language learning or acquiring processes. Those factors are related to the process of production and perception of language and are mainly based on three works of linguists that study the language learning phenomena 
from different perspectives.] INTRODUCTION [The key words that constantly appear in the investigation include: neurological, environmental and affective influences and variables, first language influence and learning strategies. Input and intake are also quite important. The term of individuality is present through the whole essay and results very important in the final conclusions together with the differentiation between acquisition and learning.] RESULTS

[The analysis consists in this information gathered being tested on seven from twenty to fifty year-old individuals that have been interviewed with several questions about their experience with language learning. All of those individuals know more than one language, nevertheless, the differences among them and the usage of the different languages is noticeable.] METHODS [The analysis of the interviews carried out depending on the age, personality and amount of languages those individuals know, provided answers to the main research questions that appear during the essay together with interesting findings that compare the knowledge that common people have about language learning and the experience they have had with it with the academic information wrote from 1980 to 20I0.] RESULTS [The main objectives include to give a clear picture of the problems that common people face in language learning and to break with the prejudices and presuppositions that common people normally have about language learning and use it as an excuse to not to put enough effort in it]; PURPOSE [ $\underline{\text { fact }}$ noticeable by comparing the interviews to the information gathered.] METHODS [Those objectives were achieved together with the answers to the research questions that are included in the final sections of the essay.] CONCLUSION (TFG 23)

An overabundance of abstract nouns (underlined in the example) makes information processing difficult. This abstract is also faulty in terms of format (2 paragraphs) and distribution of rhetorical moves: the Results section is divided by the Methods section, which is broken into two as well; and the Purpose section, which should come after the Introduction because it establishes the aims of the paper, comes after the Results and the Methods.

The last frequency worth mentioning is the type/token ratio of academic abstract nouns used. A total of Iog different nouns (see Table 4) were found, which, divided into the total number of metadiscursive nouns (352), makes a type/token ratio of 0.3I, that is, $3 \mathrm{I} \%$ of the abstract nouns used are different (i.e. I every 3 abstract nouns).

\subsection{RESULTS FOR THE LEXICO-GRAMMATICAL PATTERNS}

As can be seen in table 7, the overwhelmingly used pattern in this corpus is Determiner $+\mathrm{N}$ ( $80.68 \%$ of the cases), and, within this type, the most frequent pattern is when the noun is specified by a definite article (35.23\%). This pattern was also the most frequent in Jiang and Hyland's (2017: 6) study of abstracts written by scholars from six different disciplines $(78.3 \%)$. Likewise, the second most frequent pattern was $\mathrm{N}+$ post-nominal clause ( $17.90 \%$ in this study and $15.7 \%$ in Jiang \& Hyland's 2007). The 
post-nominal that-clause, although profusely found in Schmid's large corpus (2000), was barely used here (only 2.I4\%); the to-infinitive clause is the second most frequent $(3.98 \%)$ and the Relative clause is even more frequent (4.83\%); this latter pattern is not considered in the models adopted as reference, thereby not allowing comparisons of results.

\begin{tabular}{|c|c|c|c|}
\hline Feature & Percent & \multirow{2}{*}{\multicolumn{2}{|c|}{$\mathrm{N}=352$}} \\
\hline \multicolumn{2}{|c|}{ LEXICO-GRAMMATICAL_PATTERNS-TYPE } & & \\
\hline & Determiner_n & 284 & $80.68 \%$ \\
\hline & N_post-nominal_clause & 63 & $17.90 \%$ \\
\hline & N_be_complement_clause & 5 & $\mathrm{I} .42 \%$ \\
\hline & Demonstrative_be_n & o & $0.00 \%$ \\
\hline DETERMINER_N-' & & \multicolumn{2}{|c|}{$\mathrm{N}=352$} \\
\hline & Demonstrative_n & $5 \mathrm{I}$ & $\mathrm{I} 4.49 \%$ \\
\hline & Def_article_n & $\mathrm{I} 24$ & $35.23 \%$ \\
\hline & Indef_article_n & 30 & $8.52 \%$ \\
\hline & Zero_article_n & 56 & $15.91 \%$ \\
\hline & Possessive_n & 15 & $4.26 \%$ \\
\hline & Indefinite_n & 6 & $\mathrm{I} .70 \%$ \\
\hline & Interrogative_n & $\mathrm{I}$ & $0.28 \%$ \\
\hline & Numeral_n & $\mathrm{I}$ & $0.28 \%$ \\
\hline N_POST-NOMINA & & \multicolumn{2}{|c|}{$\mathrm{N}=352$} \\
\hline & N_that-clause & 8 & $2.27 \%$ \\
\hline & N_infinitive & I4 & $3.98 \%$ \\
\hline & N_wh-clause & 4 & I.I $4 \%$ \\
\hline & N_pp-clause & II & $3.13 \%$ \\
\hline & N_prep-clause & 9 & $2.56 \%$ \\
\hline & N_relative-clause & I7 & $4.83 \%$ \\
\hline N_BE_COMPLEM & & \multicolumn{2}{|c|}{$\mathrm{N}=352$} \\
\hline & Be_infinitive & 5 & I. $42 \%$ \\
\hline & Be_that-clause & o & 0.00 \\
\hline & Be_wh-clause & $\circ$ & 0.00 \\
\hline & Be_pp-clause & o & 0.00 \\
\hline & Be_prep-clause & o & 0.00 \\
\hline
\end{tabular}

Table 7. Frequency of lexico-grammatical patterns

The rhetorical reason for the use of simpler patterns (Det $+\mathrm{N}$ and few thatclauses) may be the one pointed out by Jiang and Hyland (2017: 6) of «limited textual space» in abstracts and could also be motivated by the fact that the abstracts analyzed here were written by novice researchers. 


\subsection{RESULTS FOR THE INTERACTIVE DIMENSION: COHESION}

As can be seen in table 8, exophoric reference (I 28 tokens) is more prevalent than anaphoric, although less frequent than endophoric reference, considering anaphoric (54 tokens) and cataphoric (170 tokens).

\begin{tabular}{|c|c|c|c|c|}
\hline Feature & $\mathrm{N}$ & Percent & & \\
\hline \multicolumn{3}{|c|}{ INTERACTIVE_COHESION-TYPE } & \multicolumn{2}{|c|}{$\mathrm{N}=352$} \\
\hline \multicolumn{3}{|c|}{ Anaphoric } & 54 & $15.34 \%$ \\
\hline \multicolumn{3}{|c|}{ Cataphoric } & 170 & $48.30 \%$ \\
\hline \multicolumn{3}{|c|}{ Deictic-exophoric } & $\mathrm{I} 28$ & $36.36 \%$ \\
\hline
\end{tabular}

Table 8. Interactive dimension: cohesion

The most common interactive type was cataphoric cohesion (48.30\%), which may be partly conditioned by how it was analyzed. The pattern $\mathrm{N}+$ postmodifying of-prepositional phrases was considered cataphoric, as in the following example:

(I) Through the analysis of the lyrics, it will be studied to what extent the musicians rely on patriarchal constructs and gender stereotypes to depict her or his significant other and how they represent a certain model of romantic heterosexual relationships (TFG_Eng_I2)

Schmid (2000: 19I) thinks that, although the referent of the noun in this type of constructions seems to be the Prepositional Phrase, «such equations are not entirely correct, since the head nouns are not conceptually identical with the information expressed as postmodifiers. Rather, the nouns refer to mental representations of this». If this is so, the referent would be exophoric, because it would be in the writer's mind, not in the text (i.e. endophoric). However, the full specification of the noun in bold (analysis) seems to rely partly on the text and partly outside: the postmodifying prepositional phrase (of the lyrics) contributes to part of the content of the noun analysis by restricting the scope of the activity carried out to a concrete entity. According Luzón Marco (1999: I, in Jiang \& Hyland 2016: 5), words like analysis are more function words than content words in that they require specification. A different issue, however, is whether that specification lies within the text or outside it. Consequently, it does not always seem feasible to identify an undeniable referent in the text. The referent of stereotypes in example 2 has been identified cataphorically as well in the post-nominal clause, following Jiang and Hyland's (2016: 8) example 9 ([...] due to their abilities to perform some redundant functions in RNA editing andlor stability). 
A very common pattern found is Det + (modifier $)+\mathrm{N}+$ past participle reducedrelative clause:

(2) After-perfect is generally understood as a perfective structure used in English (TFG_Eng_I8)

In this case, the noun structure refers to the previous Noun Group subject underlined. Examples like (2) raise the issue of whether these are cases of hyponymy or of metadiscursive nouns. They are not labels, encapsulators or shell nouns, for that matter, since they do not strictly refer to a proposition in the text, i.e. to a clausal antecedent, at least. They are rather hyponyms (or even general nouns), which name a class or group of entities. Nonetheless, Jiang and Hyland (2016: 24) include the noun structure as an example of a typical metadiscursive noun. In fact, this noun fits the definition of metadiscursive noun since it offers «writers a way of organizing discourse into a cohesive flow of information and of constructing a stance towards it» (Jiang \& Hyland 20r6: I). Consequently, the metadiscursive noun concept seems to refer to a pragmatic function of some abstract nouns that are rhetorically used in academic interactions, regardless of their cohesive function. Whether they are categorized as hyponyms, because they belong to a particular class of nouns, shell nouns (in Schmid's terms) or label nouns (in López Samaniego's 2015 terms) seems irrelevant when considering their role as unspecific abstract nouns referring to propositional entities. In other words, these nouns can be better understood when adopting the perspective that they refer to complex cognitively relational entities (either endophoric or shared knowledge), far away from the level of «things» but profiling these entities as if they were «things».

It is not always easy to locate exactly the referent for the metadiscursive noun. The same clause, or even the same phrase, tends to be the most common location for the noun's referent; however, at times, the referent is deictic (exophoric), signaling the work being done. In these cases, the definite article or the demonstrative this is used (the/this paper/research/study/thesis). Both determiners imply known information, but the propositional content that provides them with meaning has not been mentioned in the immediate co-text; in fact, the text often starts with this nominal phrase, which makes it impossible to have an anaphoric referent.

Other expressions such as the findings/results also display the same definite article, implying shared knowledge among researchers. This implication may be echoing the conventional structure of empirical research papers, which have an IMRD structure that is mirrored in academic abstracts (Jiang \& Hyland 2017: 4). Thus, readers expect writers to make reference to these research entities and, therefore, they do not need 
to be previously presented as new information (e.g. A study has been conducted...). This appeal to shared knowledge is an engagement marker in Hyland's metadiscourse model (2005a, 2005b), since the audience is asked to recognize something as familiar or accepted. It is also a sign of the taken-for-grantedness mentioned Martin and White (2005: 229): «a projection onto the intended readership of an established likemindedness with the author's position». This likemindedness favors persuasion. When used by students in their Senior Thesis abstracts, they are adopting a convention that responds to an academic disciplinary discourse. Students, in their eagerness to please their tutors and the committee that will read their work, attempt «to present themselves as competent academics immersed in the ideologies and practices of their fields» (Hyland 20I0: 134).

\subsection{RESULTS FOR THE RHETORICAL MOVES}

Table 9 displays the total number of moves in abstracts. The numbers show that they do not precisely match the five-move structure the convention establishes. If so, there should be 24 cases for each move, but they either fall short ( 6 abstracts lack a conclusion and 4 a mention of the main results) or repeat moves.

\begin{tabular}{|l|r|r|}
\hline & $\mathrm{N}$ & \multicolumn{1}{|c|}{ Percent } \\
\hline RHETORICAL_MOVES-TYPE & \multicolumn{2}{|c|}{$\mathrm{N}=\mathrm{II} 6$} \\
\hline Introduction & 25 & $2 \mathrm{I} .55 \%$ \\
\hline Purpose & 25 & $2 \mathrm{I} .55 \%$ \\
\hline Methods & 27 & $23.28 \%$ \\
\hline Results & $2 \mathrm{I}$ & $\mathrm{I} 8 . \mathrm{IO} \%$ \\
\hline Conclusion & $\mathrm{I} 8$ & $\mathrm{15} .52 \%$ \\
\hline
\end{tabular}

Table 9. Rhetorical moves

An example of an abstract with an odd distribution of moves would be TFG_ ENG_I4 below):

[Discourse is a means for transmitting ideologies values and identities. In this paper I have analysed discourse in three of the versions of the popular fairy tale Little Red Riding Hood written by Charles Perrault, The Grimm Brothers and James Finn.] INTRODUCTION

[Through the discourse of the tale, the authors represent their intentions as well as some ideologies or values that they want to show society either as praise or as criticism. To understand the reason of the authors in each time it was necessary to analyse the socio-historical context in which the tales were written.] METHODS [In this paper I have wanted to prove the intentions of the authors 


\begin{abstract}
and to show the message that they wanted to transmit.] PURPOSE [ To do this, I have analysed the texts according to the Critical Discourse Analysis discipline. As well as analysing pragmatic aspects such as speech acts, politeness strategies or Grice's maxims; I have also analysed their symbolism and the relations between language and gender.] METHODS [The paper is mainly focused on the analysis of language and gender, above all in the construction of women's identity through discourse.] INTRODUCTION [The results have proved that there is still a clear distinction between discourse to represent and refer to women's and men's behaviors,] RESULTS [which is closely linked to gender inequality.] CONCLUSION (TFG I4)
\end{abstract}

The Introduction is splitted up into two and the second sentence placed very late in the abstract. The Purpose is moved to third position and the Methods (design, procedures, etc.) is broken into two and interrupted by the Purpose (I have wanted to prove). The Results occupies only one clause that is followed by a brief Conclusion expressed in a nonrestrictive relative clause. Another example of an odd distribution of moves is TFG_23 seen above.

Therefore, in some abstracts, more than one stretch of text fulfills the same communicative function. The overabundance of Methods may be interpreted as the prominence writers give to the model they used for analysis. Not including Results or Conclusion may respond to a desire to not reveal the outcomes of their research too soon.

Graph I displays the percentages of each abstract noun category in relation to the total number of metadiscursive nouns in the abstracts, in an attempt to show their rhetorical function:

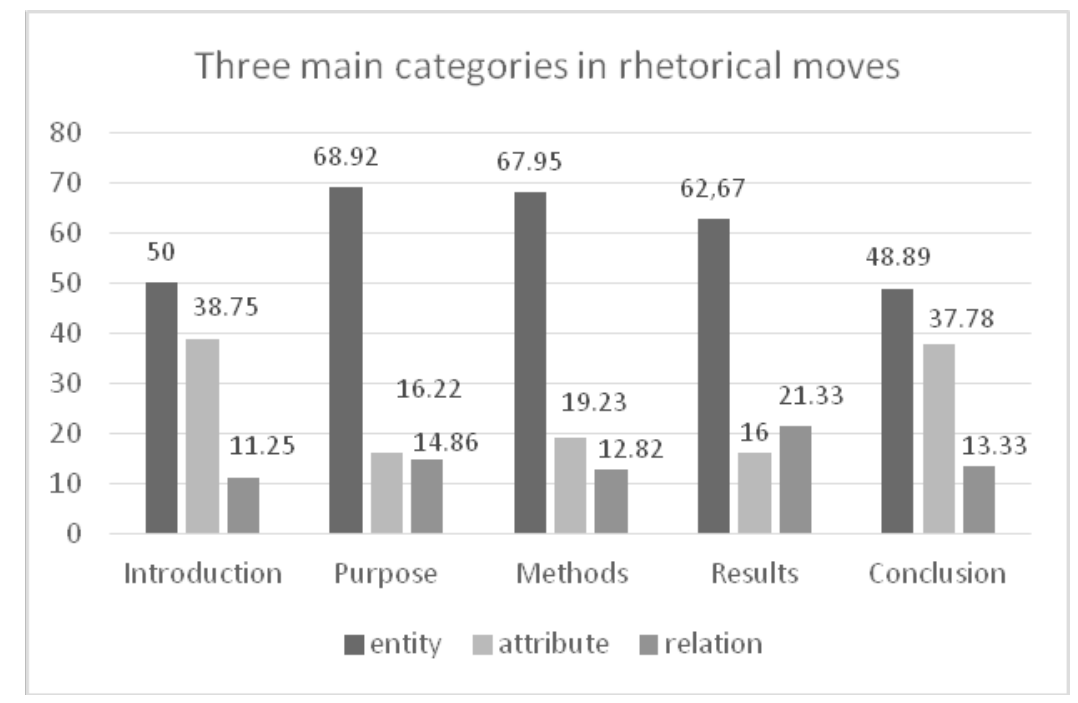

Graph I. Distribution of types of academic nouns in rhetorical moves 
The Introduction fulfills a descriptive function both referring to the object of study (Entity) and contextualizing the state of affairs (Attribute, mainly by Manner). It also holds a prominent persuasive function in trying to hook the reader into reading the rest of the paper. In the Purpose section, the intention of the researchers is made explicit and, consequently, Entity, mainly Cognition (beliefs and attitudes), is the most outstanding feature. Methods (explanatory of research design) and Results (evidential data) are also prominent in Cognition (Entity) and low in stance markers (Attribute). Relation is also most likely found in the Results section, since those nouns refer to the similarities and differences found in the Data. In Conclusions, references to entities are more balanced with attributes; like the Introduction, the conclusion intends to be persuasive in an intention to leave the reader with an overall positive impression of the research done.

\section{CONCLUSIONS}

In order to draw the general conclusions, the initial research questions will be tackled. As regards the types and frequencies of use of metadiscursive shell nouns, the quantitative analysis shows that more than half the nouns found (60.5I \%) refer to entities, concerning the paper itself (Object, $18.47 \%$ of the examples) or the writer's beliefs and attitudes (Cognition, $25.85 \%$ of the cases). Entity was also the most frequent type of noun used by expert writers in Jiang and Hyland's study (2017). Attribute (writers' stance towards the research circumstances, their positive or negative evaluation of findings or their potential and abilities) is less frequently used (24.72\%) but more abundant than Relation (I4.77\%), which is the least frequently found overall, being slightly more present (low significance level) in the Results section (2I.33\%). When distributed among the rhetorical moves (Introduction-Purpose-Methods-ResultsConclusion), the tendencies of use are reversed: more Entity is found in the three middle moves, and more Attribute in the first (Introduction) and last (Conclusion) moves, which are more prone to persuasion (to hook the readers and to clinch them, respectively). The abstracts analyzed contain a total of Iog different nouns (see table 4), which, divided into the total number of metadiscursive nouns found (352), makes a type/token ratio of 0.31 .

When observing the most frequent lexico-grammatical patterns in which these nouns are used, the overtly profuse lexico-grammatical pattern $(80.68 \%)$ for metadiscursive nouns is the simplest one: Determiner + Noun, and, within Determiners, the definite article is the most frequent $(35.23 \%)$. When a clause is involved, the 
pattern $\mathrm{N}$ + post-nominal clause is much more frequent $(17.90 \%)$ than when the noun and the clause is interposed by the verb to be (only I.42\% of the cases). These results overall match the ones found in Jiang and Hyland (2017) in texts written by well-established scholars.

In terms of the way in which metadiscursive nouns organize cohesion in the text, we see that cataphora is the most frequent cohesive relation, since the shell content or referent is often immediately after the noun. The constraints in the length of the text (about 200 words) may be the reason for such compaction. Exophoric reference is also profusely used to refer, at times, to the readers' shared knowledge (i.e. a sign of engagement) and also to other parts of the text or genre conventions (i.e. heteroglossia).

Finally, when checking whether novice research writers follow the IMRD pattern, we can conclude that, in general terms, undergraduate novice researchers are aware of the rhetorical structure of abstracts, although they give prominence (even to the extent of its overuse) to the Methods section, in an eagerness to show their acquaintance with the analytical and theoretical frameworks used. Results and Conclusions (particularly this last move) are not always present, which may decrease interest, and, consequently, debilitate the persuasive function of abstracts, because expert readers (i.e. the examining committee) are particularly eager to know the research outcomes (Results) and the general vision the student gathers from the research conducted (Conclusion). Nevertheless, some students may prefer to omit them in order to avoid revealing surprising information or simply because they are unaware of the need to include them.

Metadiscursive shell nouns fulfill the rhetorical functions of engagement and stance: in the Introduction and Conclusion by including more evaluation (Attribute) and in the middle moves by highlighting evidence, ideas, beliefs, attitudes and, very frequently, referring to the work itself (this Senior Thesis, project, paper, etc.). All in all, this study has some teaching implications for academic discourse in English: it intends to highlight the importance of abstract nouns and their metadiscursive function, to enhance the use of more elaborate lexico-grammatical patterns (e.g. $\mathrm{N}+$ that-clause) and to underline the rhetorical conventions for abstract writing.

\section{ACKNOWLEDGEMENTS}

This study has been funded by the research project EMO-FUDETT-ProPer (reference code FFI2OI3-47792-C2-2-P), granted by the Spanish Ministerio de Economía y Competitividad (Ministry of Economy and Competitiveness). 


\section{REFERENCES}

Brown, G. \& G. Yule (1983) Discourse analysis, Cambridge, Cambridge University Press.

Cabrejas Peñuelas, A. B. \& M. Díez Prados (2013) «The evaluative function of cohesive devices in three political texts», in I. Kecskes \& J. Romero (ed.), Research trends in intercultural pragmatics, Berlin, De Gruyter Mouton, pp. 317-34I.

Christiansen, T. (20iI) Cohesion: a discourse perspective, Bern, Peter Lang.

Díez, M., A. Halbach \& C. Rivas (2002) «Student difficulties with writing: a look at cohesion», in L. Sierra \& A. M. Morra (ed.), Research in academic English: communicative skills and strategies in the university context, Alcalá de Henares, Servicio de Publicaciones de la Universidad de Alcalá, pp. 69-78.

Díez Prados, M. (200I) «Frecuencia de los mecanismos de cohesión en textos escritos en lengua inglesa», in I. de la Cruz, C. Santamaría, C. Tejedor \& C. Valero (ed.), La lingüistica a finales del siglo XX. Ensayos y propuestas, Alcalá de Henares, Servicio de Publicaciones de la Universidad de Alcalá, pp. 525-530.

- (2003) Coherencia y cohesión en textos escritos en inglés por alumnos de Filología Inglesa (estudio empirico), Alcalá de Henares, Servicio de Publicaciones de la Universidad de Alcalá.

Díez Prados, M. \& A. B. Cabrejas Peñuelas (20i2) "Cohesion in American political rhetoric: The Gettysburg Address, I have a Dream and Obama's Inaugural Addressi, Estudios Ingleses de la Universidad Complutense, 20, pp. 317-34I.

FLOWERDEW, J. (2006) «Use of signalling nouns in a learner corpus», International Journal of Corpus Linguistics, II (3), pp. 345-352. DOI: I0.IO75/ijcl.II.3.o7flo.

Flowerdew, J. \& R.W. Forest(2OI5) Signalling nouns in English: A corpus-based approach, Cambridge, Cambridge University Press.

FrancIs, G. (1986) Anaphoric nouns, University of Birmingham, English Language Research.

- (1994) "Labelling discourse: an aspect of nominal-group lexical cohesion», in M. Coulthard (ed.), Advances in written text analysis, London, Routledge, pp. 83-IOI.

García-Gómez, A. (2007) Habla conflictiva como acción social. Discurso y cognición, Oviedo, Septem Ediciones.

Halliday, M. A. K. \& R. Hasan (1976) Cohesion in English, London and New York, Longman.

HyLAND, K. (2005a) «Stance and engagement: a model of interaction in academic discourse», Discourse Studies, 7 (2), pp. I73-192. 
- (2005b) Metadiscourse. Exploring interaction in writing, London and New York, Continuum.

— (2010) «Metadiscourse: mapping interactions in academic writing», Nordic Journal of English Studies, 9 (2), pp. I25-I43.

Ivanič, R. (199I) "Nouns in search of a context: a study of nouns with open- and closed-system characteristics», International Review of Applied Linguistics in Language Teaching, 29, pp. 93-II4.

JAFFe, C. (2007) Public speaking. Concepts and skills for a diverse society, Belmont, CA, Thomson Learning, Inc. [5 ed.]

Jiang, F. (K.) \& K. Hyland (20I6) «Nouns and academic interactions: a neglected feature of metadiscourse», Applied Linguistics, 37, pp. I-25. [DOI: <https://doi. org/IO.IO93/applin/amw023>]

- (2017) «Metadiscursive nouns: interaction and cohesion in abstract moves», English for Specific Purposes, 46, pp. I-I4.

López Samaniego, A. (20I5) «Etiquetas discursivas, hiperónimos y encapsuladores: una propuesta de clasificación de las relaciones de cohesión referencial», RILCE, 3I (2), pp. 435-462.

Luzón MarCo, M. J. (1999) «Procedural vocabulary: lexical signaling of conceptual relations in discourse», Applied Linguistics, 20, pp.I-2I.

Martin, J. R. \& P. R. R. White (2005) The language of evaluation: Appraisal in English, Basingstoke, Palgrave Macmillan.

Schmid, H-J. (2000) English abstract nouns as conceptual shells, Berlin, Mouton de Gruyter.

Swales, J. M. \& C. B. Feak (2009) Academic writing for graduate students, Michigan, The University of Michigan Press. [2 $2^{\text {thn }}$ ed.]

TAHARA, N. (20I4) «Metadiscursive nouns and textual cohesion in second language writing», Journal of Humanities and Social Sciences, 37, pp. 13-26. 